\title{
Reading biomedical English: Method and materials
}

\section{Lourdes Divasson}

\section{(2) OpenEdition \\ Journals}

Electronic version

URL: http://journals.openedition.org/asp/3777

DOI: 10.4000/asp.3777

ISSN: 2108-6354

\section{Publisher}

Groupe d'étude et de recherche en anglais de spécialité

\section{Printed version}

Date of publication: 1 December 1995

Number of pages: 185-191

ISSN: 1246-8185

\section{Electronic reference}

Lourdes Divasson, «Reading biomedical English: Method and materials », ASp [Online], 7-10 | 1995,

Online since 24 September 2013, connection on 23 April 2019. URL : http://journals.openedition.org/ asp/3777 ; DOI : 10.4000/asp.3777

This text was automatically generated on 23 April 2019

Tous droits réservés 


\title{
Reading biomedical English: Method and materials
}

\author{
Lourdes Divasson
}

1 English language is indispensable for scientists, professionals or technicians who wish to keep pace with the swift development of Science. For those working in the field, it is not enough nowadays to be capable of translating a biomedical text; it is also necessary to have a good command of English comprehension and oral production, as well as to be able to write scientific prose, specially if one hopes to reach international readership.

2 Unfortunately, in many Faculties of Medicine the amount of hours assigned to the teaching of English, coupled with the excessive number of students per class, makes the teaching of language skills difficult. Therefore, frequently, the lecturer can only aim to give a scientific reading course.

3 Nevertheless, this is no minor aim if one recalls Maher's claim (1987), after he examined thousands of articles from Index Medicus, that the number of those written in English had risen by $19 \%$ between 1960 and 1983. Approximately 3,000,000 papers are published every year in seven different languages in 20,000 journals. About $80 \%$ of these are written in English (Meyer 1991). Consequently, fluency in reading skills is the minimum requirement needed to be able to understand international journals, and even in-house publications, in countries where English is not the mother tongue (Maher 1987).

4 Reading biomedical English effectively is a study skill highly relevant to the needs of medical students. It is also absolutely essential to every doctor regardless of his particular field of research or where he carries out his work.

5 The aim of a reading EMP (English for Medical Purposes) course is to teach students the necessary skills to retrieve information from a written text. This means that we should follow what Johns and Davies (1983) call a TAVI approach, i.e., considering the text as a "vehicle for information", rather than the TALO principle (or text as a "linguistic object"). For the TAVI approach the focus is on recognizing main points of information and meaning rather than on grammar and lexis, although this does not mean that the latter aspects can be forgotten, as we will see later. 
6 The problem with understanding texts is due not only to the unknown vocabulary or the difficulty of certain syntactic structures but to students' lack of experience in reading professional literature. Given that there are three main types of medical prose Textbooks, Journals and Occupational Publications - the reading material to be provided will be taken from these sources.

7 Students should start by identifying each type and describing its surface structure patterning, which means they must learn to recognize the basic intellectual structure, what Van Dijk (1980) calls macrostructures, instead of relying on rules based on the analysis of isolated words or sentences.

8 Textbooks are the first genre undergraduates are most likely to face in view of the fact that many lecturers assign bibliographies in English. Textbooks represent a very good starting point to familiarize the student with scientific prose. The choice of some chapters from subjects they are taking such as Physiology or General Pathology always proves highly positive, as it is generally agreed that students' English reading proficiency is linked to their knowledge of their subject matter. If we choose, for instance, a chapter from a manual on body systems we should emphasize its rhetorical organisation as follows:

- Definition

- The organs it comprises

- shape, size, location and function

- Physiology

- Common related ailments

9 If the text to be studied is one of the Occupational English type, a case history, for example, we should stress its main structure:

- Personal details

- Clinical history

- Present complaint

- Physical examination

- Analysis

- Diagnosis

- Treatment

- Follow-up

10 With regard to Journals on medical research, it is important to distinguish between the three main types of medical English scholarly papers: research papers, reviews, and case reports. The first type accounts for approximately $60 \%$ of papers published; reviews $25 \%$, and case reports 15\% (Salager-Meyer 1992).

11 Among these papers a convenient starting point is the case report, the text-type which presents fewer difficulties both from the lexical and the syntactical point of view. In the absence of a specific structure the following format which includes the vital elements of research design was suggested (Meyer 1991):

- Case Presentation: Characteristics of the case/es dealt with in the article.

- Findings: main results

- Comments: short discussion about the findings and guidance on possible applications.

12 The third move is called Comments or Discussion because they are observations made on one or few patients only, and therefore they seldom state conclusions which can be generalized. 
Review articles generally enunciate the results of bibliographical work. In these Data Identification, Study Selection, Data Extraction and Synthesis are fundamental moves.

The reading material will be provided gradually, and will be varied and taken from the aforementioned text-types, although research articles will constitute the principal source.

When reading research papers in class we will distinguish the four moves which are considered essential and obligatory in the process of scientific enquiry, namely, Introduction, Method, Results and Discussion, in other words the IMRAD pattern of the scientific article adopted in 1960 and accepted by more than 350 biomedical journals (Meyer 1991).

6 Two optional moves can be added. The first is called Statement of the Problem, whose primary function is to introduce the subject matter of the research and, together with the Purpose, will form the Introduction. The last move, under the heading Recommendations, refers to the possible applications of the work and to the need to carry out further research (Meyer 1991).

In spite of the considerable amount of study of academic texts, particularly those of a scientific nature, by linguists and applied linguists, Research English has not received the same attention. The relatively few studies devoted to research papers are concerned either with macro structures, which we have mentioned previously, or with specific syntactic and lexical features drawn mainly from the fields of science and medicine (Swales 1986). Most of these studies involve quantitative frequency analysis. They have been carried out over the last two decades and have enabled us to establish the essential vocabulary together with a list of the main characteristics of Biomedical English all of which makes the reading of a scientific text easier. The studies of this kind that we consider most important are as follows.

\section{Previous studies}

In 1980 Salager commenced a thorough study of the lexis of medical English in the University of Los Andes in Mérida, Venezuela. She has published several partial results of this major research project. Statistical tests have enabled her to identify 1,425 roots, which form the core of medical English language, in a 100,000 word corpus of specialized medical articles. The roots have been classified into three strata: Basic Medical English (BME), Fundamental Medical English (FME), and Specialized Medical English (SME) (Salager 1983).

9 In relation to this work Bird (1984) has stated that a combined synchronic/diachronic approach would result in a considerable reduction in the number of roots in the corpus. The previous division into lexical strata, although arrived at on a statistical basis, has nevertheless enabled the author to establish a strong relationship between BME and Anglo-saxon (Germanic), FME and Latin, SME and Greek.

From this we can infer that the Latin origin of many FME roots has to be taken into account when we teach biomedical English to students with a mother tongue based on Latin, since the recognition of cognates may reduce learning and teaching tasks considerably (Salager 1983). FME, which is denoted "sub-technical" or "academic vocabulary" by some researchers, is the lexical stratum which poses the greatest 
difficulty, since they are context-bound words: it is easier to learn a new word than to assimilate it with a meaning which is different from the usual one.

Andrew Cohen et alii (1988) suggest teaching students different categories of subtechnical vocabulary -they call it "non-technica" - as it is generally accepted that words which may lead to inappropriate interpretation often carry much of the meaning of scientific writing.

In BME there is a greater frequency of terms derived from old German, the meaning of which may be unknown to our students. We have found that mentioning the Germanic word next to its classical correspondent is very useful.

In 1988, Dubois published the result of another study on lexical frequency, carried out on the basis of 52 biomedical texts. This allowed systematic use of the lists produced by those studies and involved grouping the verbs with the nouns, adverbs and adjectives in semantic fields.

\section{Frequency studies}

Several statistical frequency studies have also been carried out on the syntactic aspect of medical English literature, in an attempt to define the distinctive features and difficulties of this kind of prose (Dubois 1982; Salager 1984a).

The potentially most confusing grammatical pattern is the compound nominal phrase, a lexical structure not frequent in languages other than English. These usually do not translate literally, nor can they be transformed into simple sentences.

Another study (Salager 1987) examines the use of infinitive clauses, indicating the grammatical and rhetorical aspects of these particular structures which have to be taken into account when teaching biomedical English.

Major works on "hedging" (Adams Smith 1984; Meyer 1991), have helped us to overcome the difficulties these terms pose for students when reading articles in medical journals, and in particular when the aim is to distinguish objective statements from author-marked observations and also the scale of intensity of related linguistic items.

\section{Conclusion}

28 We believe that the application of statistical methods to create lexical inventories for teaching purposes may be of great value. We have learned through experience that the consideration of specific distinctive features in scientific prose has helped our students to learn to read biomedical English effectively. Without doubt the improvement in reading is proportional to the amount read. Lectures alone are insufficient to enable real improvement, and therefore it is necessary for students to read outside the classroom. For this purpose we should use motivating material, which may include articles on recent discoveries or controversial topics which are understandable both conceptually and linguistically.

29 We consider that if we teach the basic biomedical vocabulary and the particularly difficult or frequent syntax, and familiarize our students with the formal structure of the different kinds of texts they may encounter, we will be providing them with the means to read efficiently the plethora of biomedical literature the Index Medicus compiles. The swift 
evolution of the Health-related sciences forces professionals to permanent retraining in order for them to keep up with the recent advances in their specialties.

\section{BIBLIOGRAPHY}

Adams-Smith, D. E. 1984. "Medical discourse: aspects of author's comments". The ESP Journal 1, $17-46$.

Bird, N. 1984. Problems in compiling lexical frequency lists. A case study in EMP”. EMP Newsletter $3 / 1,30-35$.

Cohen, A. et alii. 1988. "Reading English for specialized purposes: Discourse analysis and the use of student informants". In Interactive Approaches in Second Language Reading. Cambridge: Cambridge University Press, 152-67.

Dubois, B.L. 1982. "The construction of noun phrases in biomedical journal articles". In Hoedt et alii (eds.). 1982. Pragmatics and LSP. Copenhagen: The Copenhagen School of Economics.

Dubois, B.L. 1988. “Classroom use of specialized lexicons, or what to do after the list arrives". EMP Newsletter 5/2, 20-31.

Johns, T. \& F. Davies. 1983. "Text as vehicle for information". Reading in a Foreign Language 1/1.

Maher, J. 1987. “The development of English as an international language of medicine”. EMP Newsletter 4/1, 10-22.

Meyer, F. 1991. Medical English: A scientific Reading Course. Mérida (Venezuela): Universidad de Los Andes.

Salager, F. 1983. "The lexis of fundamental medical English: Classificatory framework and rhetorical function (A statistical approach)". Reading in a Foreign Language 1/1, 34-64.

Salager, F. 1984. "Compound nominal phrases in scientific/technical literature: Proportion and Rationale". In Pugh, A.K. \& J.M. Ulijn (eds.), Reading for Professional Purposes. London: Heinemann, 136-45.

Salager, F. 1985. "Specialist medical English lexis: Classificatory framework and rhetorical function, a statistical approach". EMP Newsletter 2/2, 5-17.

Salager, F. 1987. "Infinitive clauses in medical English literature: A rhetorico-grammatical approach". EMP Newsletter 4/1, 23-33.

Salager-Meyer, F. 1992. "A text-type and move analysis study of verb tense and modality distribution in medical English abstracts”. English for Specific Purposes 11, 93-113.

Swales, J. 1986. “Citation analysis and discourse analysis". Applied Linguistics 7/1, 39-56.

Van Dijk, T. 1980. Macrostructures. Hillsdale, NJ: Erlbaum. 


\section{ABSTRACTS}

The necessity of mastering both oral and written English has become indispensable in the field of the Health Sciences. Nevertheless the need for adequate allocation of time for language study is not always appreciated in many Faculties and Schools of Medicine. Consequently the aim of a number of English courses still is to teach reading comprehension only. In this article the various patterns followed by different kinds of bio-medical texts are considered as well as their respective lexicons. Frequently occurring clauses, hedging and other characteristics of English medical writing are also taken into account. The author made use of various word inventories statistically determined in English for Medical Purposes research over the past ten years.

Aujourd'hui, le besoin de dominer l'anglais écrit et oral est devenu indispensable pour les Sciences de la santé. Néanmoins, les Facultés de Médecine ne consacrent pas assez de temps à l'enseignement de cette langue et par conséquent l'objectif de beaucoup de cours est, encore, la compréhension d'un texte écrit. Dans cette communication, on considère la différente organisation des principaux types de textes ainsi que le vocabulaire, la syntaxe, les formes de hedging et d'autres caractéristiques de cette prose scientifique. La recherche faite ces dernières décennies à propos de l'anglais médical a donné naissance à des glossaires, dont nous mentionnons les plus significatifs, pour les avoir trouvés intéressants en ce qui concerne la compréhension par la lecture.

INDEX

Mots-clés: anglais de spécialité, anglais médical, compréhension écrite

Keywords: ESP, medical English, reading comprehension

\section{AUTHOR}

\section{LOURDES DIVASSON}

Lourdes Divasson teaches at the Universidad de Tenerife. lourdes.divasson@ull.es 